\title{
Penggunaan Media Kartu Huruf Untuk Meningkatkan Kemampuan Menulis Permulaan
}

\author{
Nurlaila, S.Pd. \\ SD Negeri Lenteng Agung 11 Kecamatan Jagakarsa Jakarta Selatan \\ elanurlaila63@yahoo.com
}

\begin{abstract}
This research was motivated by the existence of facts in the field which showed that the initial writing skills of elementary school students were still lacking. Students still made a lot of mistakes (writing letters in words or sentences still lacks) and students could not compile and write words into sentences. This happens because the teacher is not maximal in using methods or learning media. By using letter card media, it is expected that the writing learning process can attract students to learn and facilitate students in memorizing and imitating letters or words. Subjects in this study were class students of the North Sumatra Grand University 11 Jagakarsa Subdistrict, Jakarta, the year 2016-2017, totaling 30 students. Based on the research results obtained, it shows that the students' initial writing ability has increased. This is evidenced by the results of the average value of students who experienced an increase in each cycle, namely (1) in cycle I, the average value of students was 69.50, (2) in cycle II, the average value of students was 74, 41, and (3) in cycle III, the average value of students is 83.06. Thus, it can be concluded that the use of letter card media can improve the writing ability of first grade students of SD Negeri Lenteng Agung 11, Jagakarsa District, South Jakarta.
\end{abstract}

Keywords: Media Card Letters, Writing Starters.

\begin{abstract}
Abstrak--Penelitian ini dilatarbelakangi oleh adanya fakta di lapangan yang menunjukkan bahwa kemampuan menulis permulaan siswa Sekolah Dasar masih kurang.Siswa masih banyak melakukan kesalahan (penulisan huruf dalam kata atau kalimat masih ada kekurangan) dan siswa kurang bisa menyusun dan menulis kata menjadi kalimat.Hal ini terjadi karena guru kurang maksimal dalam menggunakan metode atau media pembelajaran.Dengan menggunakan media kartu huruf, diharapkan proses pembelajaran menulis dapat menarik siswa untuk belajar dan mempermudah siswa dalam menghafal dan meniru huruf atau kata. Subjek dalam penelitian ini adalah siswa kelasISDNegeriLenteng Agung 11 Kecamatan Jagakarsa JakartaSelatantahunajaran2016/2017,yang berjumlah 30 orang siswa. Berdasarkan hasil penelitian yang diperolehmenunjukkan bahwa kemampuan menulis permulaan siswa mengalami peningkatan. Hal ini dibuktikan dengan hasil nilai rata-rata siswa yang mengalami peningkatan pada setiap siklusnya, yaitu (1) pada siklus I, nilai rata-rata siswa sebesar 69,50, (2) pada siklus II, nilai rata-rata siswa sebesar 74,41, dan (3) pada siklus III, nilai rata-rata siswa adalah 83,06. Dengan demikian, dapat disimpulkan bahwapenggunaan media kartu huruf dapat meningkatkan kemampuan menulispermulaan siswa kelas I SD Negeri Lenteng Agung 11 Kecamatan Jagakarsa Jakarta Selatan.
\end{abstract}

Kata Kunci : Media Kartu Huruf, Menulis Permulaan.

\section{PENDAHULUAN}

Menulis merupakan salah satu dari keterampilan berbahasa yang harus dikuasai dengan baik oleh siswa. Menulis merupakan media untuk berkomunikasi seseorang kepada orang lain. Menulis dapat melatih siswa untuk berfikir kritis dan logis, serta dapat mengungkapkan perasaan, ide,dan gagasan.

Berdasarkan pengalaman dan fakta di lapangan, siswa kelas rendah khususnya kelas I SD Negeri Lenteng Agung 11 Kecamatan Jagakarsa Jakarta Selatan masih mengalami kesulitan dalam menulis. Banyaksiswa sudah bisa membaca tetapi untuk menulis masih banyak yangkurang lancar dalam menulis. Mereka kesulitan dalam menulis kata dankalimat sederhana, siswa seringkali salah dalam menuliskan kata dankalimat ketika didikte oleh guru, terutama kata-kata yang mengandunghuruf $b, \mathrm{~d}, \mathrm{f}, \mathrm{m}, \mathrm{n}, \mathrm{w}$, y dan z. Hal tersebut dikarenakan dalam prosespembelajaran siswa cenderung kurang memperhatikan penjelasan guru,serta dalam memberikan materi guru masih murni menggunakanmetode ceramah dan respon siswa. Untuk mengatasimasalah tersebutguru dapat menggunakan metode yang bervariasi yang sesuai dengan materi maupun karakteristik siswa.

Agar siswa tertarik untuk belajar menulis, guru perlumenyediakan bahan yang menarik yang dapat menyajikan tantangan bagi siswa untuk giat secara aktif dan kreatif "mengotakatik" apa yang dihadapinya. Bahan tersebut haruslah sesuai dengan perkembangan emosi dan sosial anak. Anak di kelas permulaan (usia 6 - 8 tahun) berada pada fase bermain. 
Dengan bermain anak akan senang belajar, semakin senang anak semakin banyak yang diperolehnya.

Dalam pembelajaran menulis kalimat ini, guru dapat melakukansimulasi pembelajaran dengan menggunakan kartu huruf. Guru dapatmenggunakan strategi bermain dengan memanfaatkan kartu-kartu huruf.Kartu huruf merupakan abjad-abjad yang dituliskan pada potonganpotongan suatu media, baik karton,kertas maupun papan tulis (tripleks)(putri, 2010).Kartu huruf tersebut dapat disusun menjadi suku kata, katamaupun kalimat. Kartu-kartu huruf tersebut digunakan sebagai mediadalam permainan menyusun kata menjadi kalimat sederhana atau bisa dengan permainan kartu kata yang lain.

\section{KAJIAN PUSTAKA}

Pembelajaran pada hakekatnya merupakan suatu proses interaksi antara guru dengan siswa, baik interaksi secara langsung seperti kegiatan tatap muka maupun secara tidak langsung yaitu dengan menggunakan berbagai media pembelajaran.

Menulis merupakan kegiatan mengkomunikasikan sesuatu (gagasan,perasaan, khayalan, kehendak) secara tak langsung kepada orang lain dalam bahasa tulis yang dipahami oleh pengguna bahasa dengan menggunakan konvensi tanda-tanda dan lambang tulisan yang berlaku dalam bahasa itu.

Pembelajaran menulis permulaan merupakan bagian program pembelajaran yang ditujukan kepada kemampuan menulis di kelas-kelas awalsekolah dasar. Biasanya kegiatan menulis di kelas awal ini diajarkan bersamaan dengan keterampilan membaca, sehingga seringkali disebut dengan membaca menulis permulaan (MMP).

Tujuan menulis permulaan tentu tidak terlepas dari tujuan pengajaran bahasa Indonesia khususnya. Menulis permulaan adalah tujuan sementara, yang kemudian diharapkan siswa akan berkembang dan menggunakan kemampuan menulisnya untukmenambah pengetahuan dan mengembangkan pribadinya lebih lanjut.

Media pembelajaran adalah segala sesuatu yang digunakan sebagai perantara untuk menyampaikan pesan atau informasi dari pengirim kepada penerima.

Dalam pembelajaran menulis permulaan dengan menggunakan kartu huruf ini juga didukung dengan metode SAS agar kemampuan siswa dalam belajar menulis lebih cepat meningkat. Adapun langkah-langkah yang dilakukan adalah sebagai berikut:

- mempersiapkan silabus, buku sumber serta media/alat pembelajaran

- mengkondisikan siswa ke dalam situasi belajar

- Guru memberi contoh kalimat yang diuraikan dengan menggunakanmetode SAS

\section{METODE PENELITIAN}

Penelitian dilakukan di SD Negeri Lenteng Agung 11 Kecamatan Jagakarsa Jakarta Selatan. Alasan dipilihnya lokasi ini karena peneliti merupakan pengejar di SD Negeri Lenteng Agung 11 Kecamatan Jagakarsa Jakarta Selatan.

Subjek penelitian adalah siswa kelas Itahun ajaran2016/2017. Jumlah subjek penelitian adalah30 orangsiswa, yang terdiri dari 15 orang siswa laki-laki dan 15 orang siswaperempuan.

Pada setiap siklus dimaksudkan untuk melakukan perbaikan pada siklus satu. Langkah-langkah yang digunakan dalam siklus dua adalah sebagai berikut:

a. TahapPerencanaan, peneliti membuat rencana pembelajaran dengan perbaikan sesuai hasil refleksi pada siklus I, serta membuat lembar observasi aktifitas guru dan siswa. Kemudian mempersiapkan media kartu huruf dan sumber-sumber belajar yang lain.

b. Tahap Pelaksanaan Tindakan, tahap tindakan yang dilakukan peneliti dalam siklus dua ini tidak jauh berbeda dengan siklus satu. Setelah mengetahui kekurangan yang terdapat dalam siklus satu, peneliti akan mencoba memperbaiki pada siklus dua untuk menghindari kesalahan yang sama dalam siklus satu. Kemudian mengadakan tes di akhir siklus untuk mengetahui peningkatan kemapuan menulis siswa.

c. Tahap Pengamatan, Observasi dilakukan pada saat pembelajaran berlangsung. Setelah dilakukan prosespembelajaran, dilakukanobservasiterhadapdampaktin dakan terutama perubahan pada aktivitas dan hasilbelajar siswa. Hasil pada lembar aktivitas belajar bila menunjukpeningkatan,inimenandakan bahwa pembelajarandenganmenggunakan media kartu huruf dapat meningkatkan aktifitas dan hasil belajar siswa. Peneliti dibantu oleh gurusejawat mengamatidan mencatat perilaku siswa pada saat proses pembelajaran berlangsung, yaitu dengan mengamati sikap siswa dalam mengikuti pembelajaran.

d. Tahap Refleksi, hasil yang didapat dalam tahap observasi dikumpulkan kemudian, peneliti dibantu guru sejawat menganalisis hasil pengamatan berdasarkan atas hasil pembelajaran yang dilakukan dengan menggunakan media kartu huruf dan perilaku belajar siswa selama

mengikuti proses kegiatan belajar mengajar. Sejauh mana siswa aktif berinteraksi dan melihat kemampuan intelektual siswa. Hasil analisis data yang dilaksanakan dalam tahap ini akan digunakan sebagai

acuan atau pembanding dalam merencanakan siklus berikutnya.

Dalam penelitian ini data dikumpulkan dari hasil 
observasi dan tes hasil belajar, yang dapat dijelaskan sebagai berikut:

1. Observasi

2. Tes hasil belajar

Dalam penelitian ini, indikator keberhasilan siklusnya apabila

setiap aspek yang dinilai dan yang diobservasi memenuhi standar kelulusan minimal yaitu $80 \%$ dari seluruh jumlah siswa yang telah mencapai standar nilai KKM yaitu 75 .

\section{HASIL PENELITIAN DAN PEMBAHASAN}

\section{Siklus I}

Berdasarkan hasil tes siswa memperoleh nilai ratarata kelas sebesar 69,95. Nilai tersebut apabila dibanding dengan nilai KKM,masihberadadibawahnilaiKKM.Daritabletersebutdapa tdiketahui pula bahwa jumlah siswa yang telah mencapai nilai KKM 70 sebanyak 12 orang yang berarti40\%.Sedangkanjumlah siswa yangmemperoleh nilai di bawah KKM adalah 18 orang $(60 \%)$.Berdasarkan hasil tersebut dapat dijelaskan bahwa persentase keberhasilanmasing-masing aspek penilaian telah memperoleh nilai yang cukup, meskipun belum ada yang mencapai nilai keberhasilan siklus yaitu $\geq 80 \%$.Kelima aspek penilaian tersebut, dua diantaranya memperoleh nilai yang sangat rendah yaitu untuk aspek ke-2 dan aspek ke5.Kemudian apabila digambarkan melalui grafik pie, persentase keberhasilan tiap-tiap aspek menulis adalah sebagai berikut:

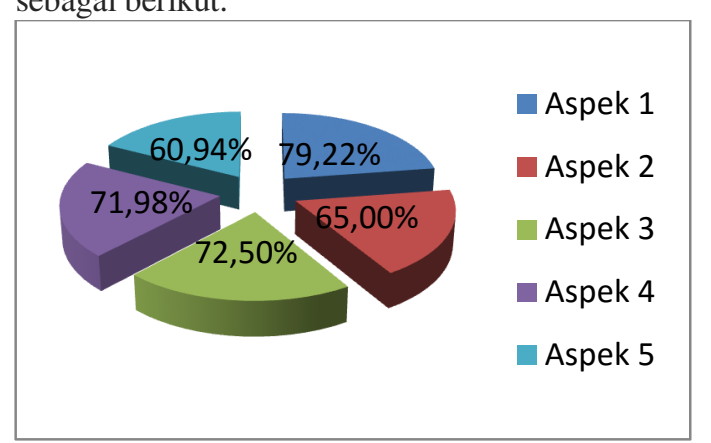

Dari grafik di atas, lebih memperjelas untuk hasil penilaian padatiap-tiap aspek. Untuk persentase keberhasilan tiap-tiap aspek adalahsebagai berikut: aspek 1 adalah 79,22\%, aspek 2 adalah $65 \%$, aspek 3adalah 72,50\%, aspek 4 adalah $71,98 \%$ dan aspek 5 adalah 60,94\%.Jadi berdasarkan hasil tersebut belum ada aspek yang mencapaiindikator keberhasilan 80\%. Oleh karena itu, diperlukan perbaikan padasemua aspek kemampuan menulis terutama pada aspek ke 2 dan 5yaitu aspek keterbacaan dan kesesuaian ukuran tulisan, sehingga diperoleh hasil yang maksimal.

2. Siklus II
Berdasarkan refleksi pada Siklus I, maka banyak kekurangan-kekurangan yang harus diperbaiki pada proses pembelajaran siklus II ini. Tujuan perbaikan pada siklus II ini adalah:

Berdasarkan hasil penelitian pada siklus II ini, hasil tes siswa memperoleh nilairata-rata kelas sebesar 74,41. Nilai tersebut apabila dibanding dengan nilai KKM, masih berada dibawah nilai KKM. Dari tabel tersebut dapat diketahui pula bahwa jumlah siswa yang telah mencapai nilai KKM 70 sebanyak 21 orang yang berarti (70\%). Sedangkan jumlah siswa yang memperoleh nilai di bawah KKM adalah 9 orang $(30 \%)$.

Berdasarkan hasil penelitian presentasi keberhasilan tiap aspek penilaian, dapat dijelaskan bahwa persentase keberhasilan masing-masing aspek penilaian telah memperoleh nilai yang cukup, meskipun belum ada yang mencapai nilai keberhasilan siklus yaitu $80 \%$.Kelima aspek penilaian tersebut, yang memperoleh nilai paling rendah yaitu aspek ke-2.Kemudianapabila digambarkan melalui grafik pie, persentase keberhasilan tiap-tiap aspek menulis adalah sebagai berikut:

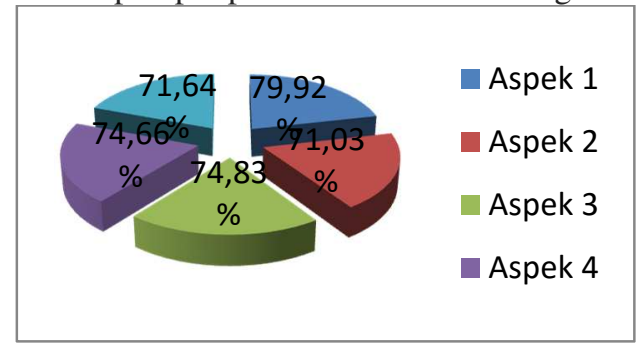

penilaian

Dari grafik di atas, lebih memperjelas untuk hasil tiap-tiap aspek. Untuk persentase keberhasilan tiap-tiap aspek adalah sebagai berikut: aspek 1 adalah 79,92\%, aspek 2 adalah 71\%, aspek 3 adalah 74,83\%, aspek 4 adalah 74,66\% dan aspek 5 adalah $71,64 \%$. Jadi berdasarkan hasil tersebut belum ada aspek yang mencapai indikator keberhasilan 80\%. Oleh karena itu, diperlukan perbaikan pada semua aspek kemampuan menulis terutama pada aspek ke-2 yaitu aspek keterbacaan, sehingga diperoleh hasil yang maksimal.

3. Siklus III

Berdasarkan refleksi pada Siklus II, maka banyak kekurangankekurangan yang harus diperbaiki pada proses pembelajaran siklus III ini. Tujuan perbaikan pada siklus III ini adalah:

1) Hasil tulisan siswa dapat dibaca.

2) Siswa dapat menulis sesuai dengan petunjuk guru

Untuk mencapai tujuan perbaikan tersebut, maka disusun langkah-langkah perencanaan sebagai berikut:

1. Menyusun rencana perbaikan pembelajaran dengan menerapkan media kartu huruf.

2. Mempersiapkan media kartu huruf dan kain flanel. 
3. Mempersiapkan instrument yang akan digunakan dalam proses pembelajaran, yaitu lembar observasi aktivitas guru dan siswa.

4. Mempersiapkan soal tes untuk mengetahui kemampuan menulis permulaan siswa setelah dilakukan tindakan III.

Pelaksanaan proses pembelajaran menulis permulaan pada siklus III ini terdiri atas 2 x pertemuan dan alokasi waktu untuk

masing-

masing pertemuan adalah 2 x 35 menit. Pertemuan I dilaksanakan pada hari Selasa, tanggal 2 Mei 2017, sedangkan pertemuan II dilaksanakan pada hari Kamis tanggal 4 Mei 2017.

Pada pertemuan kedua, guru mengkondisikan siswa agar siap untuk mengikuti tes. Guru bertanya jawab dengan siswa agar siswa tidak tegang. Kegiatan inti difokuskan pada pelaksanaan tes untuk mengetahui kemampuan siswa dalam menulis setelah digunakanmedia kartu huruf.

Hasil tes siswa memperoleh nialai rata-rata kelas sebesar 83,59. Nilai tersebut telah melampaui nilai KKM. Dari data tersebut dapat diketahui pula bahwa jumlah siswa yang telah

mencapai nilai KKM 70 sebanyak 24 orang yang berarti $80 \%$.

Sedangkan jumlah siswa yang memperoleh nilai di bawah KKM hanya 6 orang $(20 \%)$.

Berdasarkan hasil penelitian presentase keberhasilan tiap aspek penilaian menulis, dapat dijelaskan bahwa persentase keberhasilan masing-masing aspek penilaian telah memperoleh nilai yang cukup yaitu $80 \%$.Kelima aspek penilaian tersebut telah mencapai indikator keberhasilan siklus.

Kemudian apabila digambarkan melalui grafik pie, persentase keberhasilan tiap-tiap aspek menulis adalah sebagai berikut:
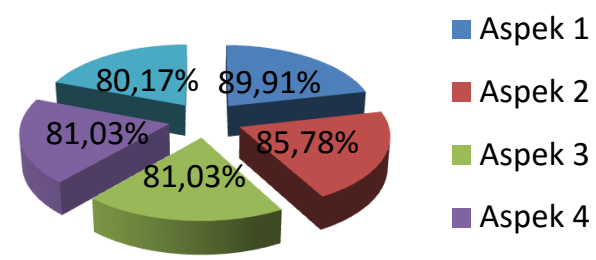

Aspek 2

Aspek 3

Aspek 4

Aspek 5

Dari grafik di atas, lebih memperjelas untuk hasil penilaian padatiap-tiap aspek. Untuk persentase keberhasilan tiap-tiap aspek adalahsebagai berikut: aspek 1 adalah 89,91\%, aspek 2 adalah 85,78\%, aspek3 adalah
$81,03 \%$, aspek 4 adalah $81,03 \%$ dan aspek5 adalah $80,17 \%$. Jadi berdasarkan hasil tersebut semua aspek telah mencapai indicatorkeberhasilan $80 \%$.Oleh karena itu, penelitian dianggap berhasil.

Berdasarkan hasil tes menulis permulaan dengan penggunaan media kartu huruf pada siklus III dan hasil lembar observasi aktivitas guru dan siswa pada siklus III diperoleh hasil sebagai berikut:

1. Nilai rata-rata siswa adalah 83,59 yang berarti telah melampaui nilai

KKM 70, dan jumlah siswa yang mencapai nilai KKM adalah sebanyak27 orang yang berarti $80 \%$. Sedangkan jumlah siswayang memperoleh nilai di bawah KKM adalah6orang (20\%).Standar kelulusan yang menjadi indikasi keberhasilan siklus dalam penelitian ini adalah $80 \%$.

2. Hasil observasi aktivitas siswa menunjukkan bahwa semua indikator telah memperoleh nilai 5 .

3. Hasil observasi terhadap kegiatan guru menunjukkan bahwa dari

kegiatan guru memperoleh nilai 5.

Dengan demikian, pada siklus III ini penelitian dianggap selesai karena telah mencapai hasil sesuai dengan indikator keberhasilan siklus dan berarti bahwa penggunaan media kartu huruf dapat meningkatkan kemampuan menulis permulaan siswa.

Dalam proses pembelajaran menulis permulaan dengan menggunakan media kartu huruf ini mengamati aktivitas guru dan siswa.

Berdasarkan hasil observasi pada siklus1, 2 dan 3, diperoleh

data sebagai berikut: (1) pada siklus I, 1 indikator memperoleh nilai 3, 2 indikator memperoleh nilai 4 dan 1 indikator memperoleh nilai 5; (2) pada siklus II, 2 indikator memperoleh nilai4 dan 2 indikator memperoleh nilai 5; dan (3) pada siklus III, semua indikator memperoleh nilai B.

Apabiladigambarkan menjadi sebuah grafik batang, maka akanterlihat seperti grafik berikut:

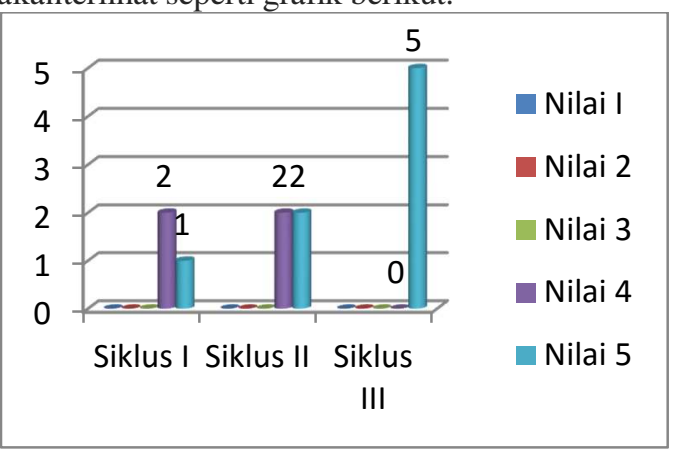

Dari grafik tersebut di atas, terlihat bahwa hasil observasi terhadap aktivitas siswa meningkat pada setiap siklusnya hingga mencapai indikator keberhasilan siklus 
80\%. Kemudian untuk aktivitas guru, meliputi 7 indikator yaitu:

a. Membuat rencana pembelajaran tiap siklus

b. Mempersiapkan media pembelajaran

c. Memberikan arahan dan penjelasan tentangcara menyusun dan menulis kata/kalimat.

d. Memberikan latihan menyusun dan menulis kata/kalimat

e. Bertanya jawab dengan siswa

f. Melakukan penilaian dalam proses dan produk pembelajaran

g. Memberikan penguatan terhadap aktivitas dan kreatifitas siswa siklus

Berdasarkan hasil observasi terhadap kegiatan guru pada

I, II dan III, diperoleh hasil sebagai berikut: (1) pada siklus I, 3 indikator memperoleh nilai 4 dan 4 indikator memperoleh nilai 3; (2) pada siklus

II,

4 indikator memperoleh nilai 4 dan 3 indikator memperoleh nilai 5, dan (3) pada siklus III semua aktivitas guru mendapat nilai 5.

2. KemampuanMenulis Permulaan Siswa Setelah Menggunakan Media Kartu Huruf ini,

Kemampuan menulis permulaan siswa pada penelitian

berdasarkan lima aspek penilaian, yaitu kelengkapan, keterbacaan, kerapihan, kesesuaian bentuk tulisan dan kesesuaian ukuran tulisan.

Padamasing-masing aspek penilaian telah ditentukan indikator keberhasilan setiap siklusnya yaitu $80 \%$. Dari tiga siklus yang telah dilakukan diperoleh nilai tiap aspeknya sebagai berikut: (1) pada siklus I, persentase keberhasilan tiap-tiap aspek adalah aspek 1 adalah $79,22 \%$, aspek 2 adalah $65 \%$, aspek 3 adalah 72,50\%, aspek 4 adalah 71,98\% dan aspek 5 adalah 60,94\%.; (b) pada siklus II, persentasekeberhasilan tiap-tiap aspek adalah aspek 1 adalah 79,92\%, aspek 2adalah $71 \%$, aspek 3 adalah $74,83 \%$, aspek 4 adalah $74,66 \%$ dan aspek 5 adalah 71,64\%.; dan (3) pada siklus III,persentase keberhasilan tiaptiap aspek adalah aspek 1 adalah $89,91 \%$, aspek 2 adalah $85,78 \%$, aspek 3 adalah $81,03 \%$, aspek 4 adalah $81,03 \%$ dan aspek 5 adalah $80,17 \%$.

Apabila dilihat secara keseluruhan nilai siswa, yaitu melalui nilai rata-rata siswa, kemampuan siswa dalam menulis permulaan dengan menggunakan media kartu huruf adalah sebagai berikut: (1) pada siklus I, nilai rata-rata siswa sebesar 69,95, (2) pada siklus II, nilai rata-rata siswa sebesar 74,41, dan (3) pada siklus III, nilai rata-rata siswa adalah 83,59. Kenaikan nilai rata-rata siswa pada setiap siklusnya dapat diilustrasikan pada grafik berikut:

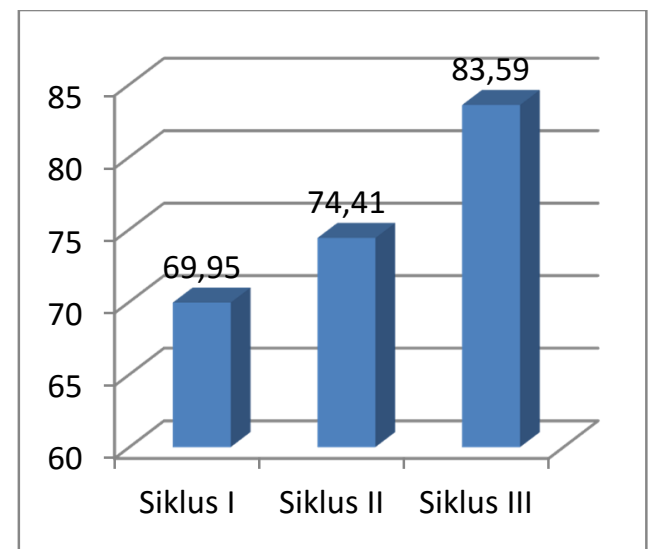

Berdasarkan hasil penelitian pada siklus I, II dan III, dapat disimpulkan bahwa dengan menerapkan media kartu huruf dalam pembelajaran menulis permulaan dapat meningkatkan kemampuan menulis siswa kelas I SD Negeri Lenteng Agung 11 Kecamatan Jagakarsa Jakarta Selatan.

\section{KESIMPULAN}

Berdasarkan hasil penelitian tentang peningkatan kemampuan menulis permulaandengan menggunakan media kartu huruf yang telah dilaksanakan di kelas I SD Negeri Lenteng Agung 11 Kecamatan Jagakarsa Jakarta Selatan dapat disimpulkan sebagaiberikut:

1. Dalam proses pembelajaran menulis permulaan dengan media kartu huruf yang meliputi langkah-langkah sebagai berikut: (a) mempersiapkan media kartu huruf, (b) memilih metode yang tepat, (c) menyusun rencana pembelajaran, (d) siswa menyusun dan menuliskan kata dan kalimat, dan (e) evaluasi. Dalam proses pembelajaran ini, aktivitas guru dan siswa, mengalami peningkatan pada setiap siklusnya,dan hasil akhir pada siklus III semua aktifitas siswa mendapat nilai 5.

2. Kemampuan menulis permulaan siswa setelah menggunakan media kartu huruf mengalami peningkatan pada setiap siklusnya. siswa dapat penulis katadan menulis kalimat sederhana yang berhubungan dengan huruf $\mathrm{b}, \mathrm{d}, \mathrm{n}, \mathrm{m}, \mathrm{f}, \mathrm{y}, \mathrm{w}$, dan $\mathrm{z}$ kemudian untuk penilaian tiap-tiap aspek dalam menulis juga mengalami peningkatan dengan mencapai target $75 \%$ adapun nilai akhir dari tiap-tiap aspek kelengkapan 92,50\% aspek keterbacaan87,50\%, aspek kerapihan78,33\%,aspek kesesuaian bentuk tulisan $78,33 \%$, dan aspek kesesuaian ukuran tulisan 73,67\%. kemudian secara keseluruhan untuk nilai rata-rata siswa juga mengalami peningkatan, yaitu (1) pada siklus I, nilai rata-rata siswa sebesar 69,95, (2) pada siklus II, nilai rata-rata siswa sebesar 74,41, dan (3) pada siklus III, nilai ratarata siswa adalah 83,59.

\section{DAFTAR PUSTAKA}


[1] Arsyad,Azhar.(2007). MediaPembelajaran. Jakarta: Pt. Raja GrafindoPersada.

[2] Churiyah, dkk.(2009). Pembinaan dan Pengembangan Pembelajaran Bahasadan Sastra Indonesia. Bandung: UPI Press.

[3] Depdiknas.(2006). Kurikulum2006: Mata Pelajaran Bahasa IndonesiaSekolah Dasar dan Madrasah Ibtidaiyah. Jakarta: Depdiknas.

[4] Fitriyah, N.F. (2010). Penggunaan Media Kartu Huruf dan Kartu Kata melaluiPermainan untuk Meningkatkan Kemampuan Menulis Permulaan SiswaKelas I SDN Sidimoro 01 Kecamatan Bululawang.Skripsi UNM : FIP

[5] Hartati dan Churiyah.(2010). Pendidikan Bahasa dan Sastra Indonesia diKelas Rendah. Bandung: UPI Press.

[6] Kasbolah,K.(1998/1999).Penelitian Tindakan Kelas. Jakarta: Departemen Pendidikan dan Kebudayaan Direktorat Jendral Pendidikan Tinggi ProyekPendidikan Sekolah Dasar.

[7] Putri D.E. (2010). Meningkatkan Keterampilan Menulis Permulaan dengan Menggunakan Kartu Huruf pada Siswa Kelas I SDN I Saung Baung Muara Bulian.Universitas Jambi : Skripsi. FKIP

[8] Resmini, dkk.(2006). Pembinaan dan Pengembangan Pembelajaran Bahasadan sastra Indonesia.Bandung: UPI Press.

[9] Resmini dan juanda.(2007). Pendidikan Bahasa dan Sastra Indonesia di KelasTinggi. Bandung: UPI Press.

[10] Resmini dan Hartati.(2007). KapitaSelekta. Bandung: UPI Press.

[11] Sanjaya, Wina. (2008). Kurikulum dan Pembelajaran. Teori dan PraktikPengembangan KTSP. Jakarta: Kencana, Prenada Media Group.

[12] Surya, Muhammad. (2003). Psikologi Pembelajaran dan Pengajaran. Bandung: Yayasan Bhakti Winaya.

[13] Solchan, T.W. dkk. (2008). Pendidikan Bahasa Indonesia di SD. Jakarta:Penerbit Universitas Terbuka.

[14] Supardi dan Suhardjono.(2011). Strategi Menyusun Penelitian Tindakan Kelas.Yogyakarta: Penerbit Andi.

[15] Tarigan, H.G. (2008). Menulis Sebagai Suatu Keterampilan Berbahasa.Bandung: Angkasa.

[16] Tim Penyusun Kamus Pusat Pembinaan dan Pengembangan Bahasa (1988). Kamus (KBBI)
Jakarta: Depdikbud Perum Balai Pustaka

[17] Universitas Pendidikan Indonesia.(2012). Pedoman Penulisan Karya Ilmiah. Bandung: Departemen Pendidikan Nasional UPI Bandung. 